\title{
ANALIZA IDENTITETA MARKE USLUGE
}

\author{
Dinko Jukić ${ }^{12}$ \& Božica Dunković ${ }^{13}$
}

UDC / UDK: 658.626:658.89

JEL classification / JEL klasifikacija: L80, M30

DOI: https://doi.org/10.22598/pi-be/2021.15.1.107

Scientific review / Pregledni znanstveni rad

Received / Primljeno: November 09, 2020 / 09. studenog 2020.

Accepted for publishing / Prihvaćeno za tisak: February 26, 2021 / 26. veljače 2021.

\section{Sažetak}

U radu se provodi raščlamba karakteristika identiteta marke. Najprije se definira pojam identiteta marke, a potom se redefinira, analizira $i$ sintetizira pojam imidža marke. Identitet $i$ imidž marke prikazuju se s komunikacijskog i semiotičkog aspekta $i$ komparira s ulogom mita $i$ samopredodžbe potrošača. Cilj je istražiti, predstaviti $i$ analizirati identitet $i$ imidž marke usluge sukladno potrošačevoj paradigmi. Rad se sastoji od tri dijela. U prvom dijelu analizira se identitet marke sa semiotičkog $i$ psihološkog aspekta, a u drugom dijelu se raspravlja i analizira sadržaj imidža marke. Na kraju se raspravlja o doživljenoj kvaliteti usluge. Marka je ponajprije potrošačka impresija pa tek potom spoznajna vrijednost. Izgradnja marke podrazumijeva stvaranje razlike, a stvaranje se odvija pomoću mentalnih struktura potrošača. Imidž promatramo kao rezultat komunikacijskog procesa, ali i kao potrošačku predodžbu i iskustvo. Imidž usluge stvaraju podjednako zaposlenici i neposredno iskustvo potrošača. Zaključuje se da uloga doživljene kvalitete usluge proizlazi iz zadovoljstva potrošača i imidža poduzé́a.

Ključne riječi: marka; identitet; imidž; potrošač; usluga.

\section{UVOD}

Ideja marke u marketinškoj doktrini jedna je od najvažnijih pojmova jer povezuje potrošače, proizvođače i proizvod, odnosno uslugu u zajednički kontekst. Sama sintagma marke poprimila je velika značenja. $S$ jedne strane, marka je znak

\footnotetext{
${ }^{12}$ dr.sc. Dinko Jukić, Trgovačka i komercijalna škola "Davor Milas“ Osijek, Hrvatska, E-mail: dinkojukic.phd@gmail.com

${ }^{13}$ dr.sc. Božica Dunković, Upravni odjel za ruralni razvoj, Osijek, Hrvatska, E-mail: bozica.dunkovic@obz.hr
} 
prepoznavanja, diferencijacija proizvoda ili usluge, dodana vrijednost, financijska vrijednost, odnos s potrošačem i imidž. S druge strane, marka je fenotip: kulturni objekt, socijalni fenomen, psihološki odraz, metafora, simbol i jezični znak. Marka je danas kolektivna prezentacija. Marka u postmodernom svijetu nadilazi klasično shvaćanje marke. Marka komunicira na semiotskoj razini, označuje sjećanje, prošlost i budućnost (Vranešević, 2007:79). Ona daje proizvodima i uslugama značenje i svrhu.

Marku shvaćamo kao poruku koju potrošači dekodiraju, ali ona nikada nije rezultat samo jedne značajke, kao što ni identitet marke nije samo fizičko obilježje ili refleksija na okolinu. Marke su postale ključne u stvaranju modernog društva (Kapferer, 2008:9). Budući da su marke toliko integrirane u svim društvenim sferama, na mikro i makro ekonomskoj razini, antropološkim i psihološkim obrascima tumačenja pa sve do semiotskih i interdisciplinarnih kulturnih karakteristika, i umjetničkim razinama, marka doista postaje fenomen.

U radu se analizira marka polazeći od paradigme potrošača, tj. njenih specifičnih fenomena kao što su osobnost marke, kreiranje identiteta i percepcija imidža. Prvi dio započinje raščlambom identiteta u kojem se analizira vizija marke i redefinira konstrukt identiteta s ontološko-semiotskog aspekta. Uvodi se filozofski pojam Drugoga kako bi se redefinirala marka s aspekta pošiljatelja i primatelja poruke. Drugi dio raspravlja o imidžu marke s psihološko-socijalnog aspekta povezujući prizmu identiteta s potrošačevim percepcijama. Ovdje se tumači samopredodžba potrošača, mitska struktura marke i društveni utjecaj. Treći dio analizira doživljenu kvalitetu marke usluge. Naglašava se važnost uloge zaposlenika jer su oni promotori usluge. Također, važno je potrošačevo iskustvo s markom jer predstavlja početni stadij kontakta na osnovu kojeg se formiraju impresije.

Svrha rada je istražiti, prikazati i analizirati identitet marke s psihološkog, sociološkog i marketinškog aspekta. Cilj rada je ukazati na važnost identiteta i imidža marke u kontekstu paradigme potrošača. U radu se prikazuje interdisciplinarni teoretski okvir u kojem se analizira identitet marke usluga. Posebno se izdvaja fenomenološki pristup identiteta marke prema Kapfererovoj teoriji koja objedinjuje psihološki konstrukt osobnosti marke, samopredodžbu potrošača i odnos. Rad je namijenjen detaljnijem, preciznijem i analitičko-kritičkom propitivanju fenomena identiteta marke. Znanstveni doprinos rada očituje se u nadovezivanju prijašnjih istraživanja posebice s područja identiteta i imidža marke, raščlambi potrošačevih impresija kao i u pregledu literature. Također, doprinos se očituje u korelaciji s drugim znanstvenim disciplinama kao što su razne kulturološke teorije, psihologija, sociologija i filozofija.

\section{METODOLOGIJA ISTRAŽIVANJA}

Za potrebe istraživanja korištena je kvalitativna analitičko-sintetička metoda koja ima za cilj raščlanjivanje pojma marke na segmente radi detaljnijeg analiziranja. Kao model razumijevanja koristi se metoda hermenautičke spirale (Schmidt, 2006:4), koja upućuje da se dijelovi neke cjeline mogu razumjeti jedino na osnovu razumijevanja ukupne cjeline. Pojedini pojmovi identiteta i imidža marke proširuju ukupno značenje 
fenomena marke. Prema tome, u ovoj se studiji koriste paralelno dva pristupa: kritičkorealistična metoda i fenomenološka metoda znanstvenog istraživanja (Willig, 2013:4850). Kvalitativnom metodom kritičko-realističnog pristupa otkrivamo značenje, a fenomenološkom metodom prikazujemo teksturu samog istraživanja, tj. proširujemo razumijevanje. Takva interpretacija fenomenološke analize inicijalnu deskripciju stavlja u odnos prema širem kulturnom, teorijskom i društvenom kontekstu, odnosno kontekstu identiteta marke usluge. Korištene su polazne teorije heksagonskog identiteta marke (Kapferer, 2008), imidža marke (Keller et al, 2008) i model marke usluge (Grönroos, 2007a).

Metode koje su korištene u izradi ovoga rada su interpretativne, dekonstrukcijske, deskriptivne, metode analize, sinteze, dedukcije, konkretizacije i komparativne metode. Provedena je pojmovna analiza identiteta i imidža marke u kojem definiramo i određujemo sadržaj imidža te provodimo diviziju opsega pojmova identitet marke. Sukladno tome, u radu se primjenjuje deskriptivna, klasifikacijska i eksplanacijska metoda. U radu se predstavlja, raspravlja, analizira i redefinira uloga izgradnje identiteta i imidža marke s aspekta usluga. Cilj rada je prikazati, analizirati i istražiti značenje uloge identiteta i imidža marke usluge u kontekstu potrošačeve paradigme. Jedinice analize istraživanja su identitet marke, imidž marke i usluga marke koje će se dekonstrukcijskom analizom prikazati, opisati, protumačiti i razumjeti. Središnji koncept je fenomen marke.

Ograničenja istraživanja proizlaze iz same prirode kvalitativne metodologije, tj. odabrane epistemiološke pozicije. Fenomenološki pristup proučavanja identiteta i imidža marke bavi se kvalitetom i teksturom samog fenomena marke, a cilj je jasnije razumijevanje i analiziranje marke. Ujedno, realistički pristup polazi od generiranja znanja i analiziranja pojmova pa samim time nema kvantitativnih pokazatelja koji bi testirali navedene modele $\mathrm{i}$ teorijske analize. Također, rad je interdisciplinarnog karaktera pa je za njegovo razumijevanje potrebno komparirati različite društveno-humanističke doktrine. Daljnja istraživanja mogu proizaći s aspekta kvantitativnih istraživanja koja bi uključila testiranje jedinica istraživanja iz ovoga rada, konkretno percepciju imidža marke i konstrukte identiteta.

\section{DIJALEKTIKA IDENTITETA MARKE}

Koncept identiteta marke privukao je interes područja upravljanja markom, teorije ponašanja potrošača i strategije marketinga. Preduvjet izgradnje uspješne marke svakako je stvaranje odgovarajućeg identiteta marke. Identitet marke možemo poimati kao viziju iza koje se nalazi marka sa svojim vrijednostima i posebnosti na koju će reagirati potrošač. Identitet predstavlja osnovnu premisu marke, a imidž predstavlja potrošačeve emotivne i racionalne impresije prema markama (Jukić, 2016:49-76).

Marka je vizija koja stvara potrošačeve vizije (Kapferer, 2008:171). Te vizije čine potrošačeva uvjerenja i percepcije koje dovode do vjernosti te u konačnici do fenomena marke kulta (Acosta \& Devasagayam, 2010: 168). Vizije predstavljaju jezgrenu vrijednost same marke, njenu esenciju. Vizija marke obuhvaća segmente marke 
poduzeća (Balmer, 2001:248-291; Balmer \& Gray, 2003: 972-997), osobnosti marke (Aaker, 1997:347-357) i tržišnu vrijednost (Aaker, 1991:15-28; Aaker, 1996:303-337; Aaker, 2004:16-27). Neki autori navode pojam DNK marke (Govindarajan \& Trimble, 2005:47-76; Prahalad \& Ramaswamy, 2004:5-14), ali u konačnici, vizija ujedinjuje unutarnje i vanjske činitelje paralelno sa željenom slikom o proizvodu, ali i svim asocijacijama. Možemo reći da je vizija marke simbioza ideje i njene realizacije. Ideja koja predstavlja određeno vjerovanje koje marka poručuje, tj. njenu specifičnu mitizaciju, dok realizacija čini opipljivi produkt. Jednostavno rečeno, vizija marke čini identitet.

Identitet marke promatramo $s$ aspekta tržišne vrijednosti i tržišne vrijednosti utemeljene na potrošaču. Samim time, identitet marke predstavlja izvor pozicioniranja. Koncept identiteta marke relativno je nov. Ključno pitanje raščlambe identiteta marke je: što marku čini markom? Marka je ideja. Vizija koja se, sukladno životnom ciklusu proizvoda (Kotler et al, 2016:274), mijenja. Marka ne bi nikada trebala napustiti ranu fazu zrelosti jer u svojoj nutrini podrazumijeva stalno razvijanje. Također, zrelost marke ujedno označava i početak njenog završetka, dakle odumiranje. Pojam životnog ciklusa proizvoda predstavlja jednu od najplastičnijih koncepcija koja se koristi u teoriji marketinga (Meler, 2005:194).

Samim time, asocijacije zrelosti mogu negativno utjecati na reputaciju marke. Ta ideja promjene u samom je korijenu genoma marke. Zbog tih korijenskih, epistemoloških ideja, marka dozvoljava promjene segmenata identiteta. To nisu ključne promjene, jer tada to više ne bi bila ista marka i potrošači bi je teže percipirali (Haig, 2004: 105-121). Stoga se identitet razmatra kao dijalektički fenomen unutar nekoliko simultanih tendencija. Ono što je nedvojbeno jest hipostaza pojma identiteta i konstrukcija identiteta marke kao kulturnog identiteta. Načelo destruktivne kreativnosti (Bauman, 2011:28-34) predstavlja načelo kreativnog stvaranja, tj. oblika kulturne prakse. Takav stvaralački odnos zapravo je primaran, jer ga menadžeri stvaraju upravo kroz elemente identiteta (Keller et al, 2008:128-166). Međutim, u samom korijenu takvog identiteta upravo je konstrukt samopredodžbe potrošača (Aaker, 1996:67-103; Keller et al, 2008:419-422; Kapferer, 2008: 182-193). Ontološki gledano, središnji je pojam "Drugoga" kao i onoga koji uključuje njegovo priznanje.

Drugi time postaje odlučujući entitet u stvaranju vlastitog kulturnog, socijalnog, psihološkog i potrošačkog identiteta. Tek u takvoj komunikaciji pojam identiteta zadobiva svoju relaciju komunikacijske poruke. Također, takva dimenzija uključuje konstrukt priznanja Drugog i definira naš vlastiti identitet. Takva konstrukcija vlastitog kulturno-potrošačkog identiteta stvara temelj postmodernim markama. U takvom hiperpotrošačkom društvu, u kojem je razlikovnost ključna, a identitet samo jedan od oblika individualizacije koja služi kao preobrazba potrošačevog identiteta u zadani oblik, otvara se pitanje simulakruma (Baudrillard, 2017:121-129). Simbolička interakcija preko koje se uspostavlja odnos potrošača s Drugim krucijalna je za stvaranje identiteta marke. Drugi, promatrajući ga u širem smislu kao referentni oblik, postaje dijalektički uvjet vlastitog konstitutivnog segmenta opstanka. Analiziranje identiteta marke dovodi nas do paradoksa promjenjivosti identiteta.

Poznavajući identitet marke, otvara se prostor ekspresije same biti marke (Kapferer, 2001). Tek kada znamo strukturu marke možemo bez bojazni mijenjati 
elemente identiteta. Međutim, da bismo mijenjali taj genom marke, bitna je upravo sama poruka marke. Poruka je temelj na kojem izgrađujemo identitet marke i ona je središte same marketinške komunikacije. Poruka marke, u komunikacijskom smislu, označava prenošenje informacija, preciznije slanje određene vizije potrošačima i prihvaćanje tog imidža. Kreativne marke uvijek nameću nove standarde, a neprestano natjecanje dovodi do fenomena kloniranosti, što je ujedno i najnepoželjnije u kontekstu identiteta. Veća sličnost znači slabiju prepoznatljivost. Potrošači egzistiraju u razdoblju marketinške sličnosti (Kapferer, 2008:173). Kompleks sličnosti marki vrlo zorno se ocrtava, ponajviše u marketingu neprofitnih organizacija (Jukić, 2019a: 10-18) kao što su škole, knjižnice, muzeji i slično.

Identitet možemo promatrati putem tri perspektive (de Chernatony \& McDonald, 2003:19): kao unutarnju, vanjsku i vremensku perspektivu. Unutarnja perspektiva obuhvaća grafički znak, instrument zaštite, uštedu vremena ili smanjivanje kupovnog rizika, osobnost i identifikaciju. Pod pojmom vanjske perspektive obuhvaćamo imidž i odnos svih procesa razmjene (Belk 1988: 139-168; Belk, 2013: 477-500), dok pod pojmom vremenske perspektive obuhvaćamo razvojni subjekt. Unutarnja perspektiva služi za privlačenje i zadržavanje potrošača, a vanjska za pružanje veće vrijednosti potrošaču. Posljednja, vremenska, aludira na razvoj marke. Identitet marke obuhvaća poruku koju marka odašilje kroz naziv, vizualne i zvučne elemente i oglašavanje. Imidž podrazumijeva vjerovanja i emocije prema specifičnim markama, odnosno potrošačevu impresiju. Sama esencija identiteta marke polazi od jezgre, stila i teme marke. Jezgra marke predstavlja samu bit marke, njen fundamentalni i genetski kod (Smith, 2003:99100) koji se s vremenom nadograđuje i popravlja. Stil marke označava kulturu prenošenja marke, sveukupnost vrijednosti marke, osobnost i imidž marke i njenu refleksiju na potrošača. Tema marke obuhvaća način komuniciranja kroz oglašavanje, fizički izgled, odraz i odnos.

Raščlanimo karakteristike pozicioniranja identiteta marke kroz četiri distinktivne karakteristike: beneficije, ciljane mete, prigode i konkurencije. Izvor pozicioniranja identiteta marke promatramo na relaciji pošiljatelj-primatelj gdje su prvi i posljednji elementi, beneficija i konkurencija na strani potrošačeve percepcije, a središnji koncepti ciljane: mete i prigode, na strani elemenata identiteta. Konkretno, beneficija označava ispunjene obećanja marke te je zbog toga ključna u samom kreiranju marke. Identitetom marke kreira se jedinstvena poruka koja će biti prepoznatljiva i tržišno prihvatljiva. Konkurencija, kao posljednja etapa pozicioniranja identiteta marke, također je ključna, jer identitet marke čine značajke kojima se u potrošača žele postići odgovarajuće impresije. Identitet je samim time sredstvo za kreiranje imidža, a on se manifestira kroz ciljano tržište, tj. kroz potrošačevu percepciju i odnosima s potrošačima. Slika 1. prikazuje raščlambu karakteristika pozicioniranja identiteta marke. 
Slika 1. Raščlamba karakteristika pozicioniranja identiteta marke

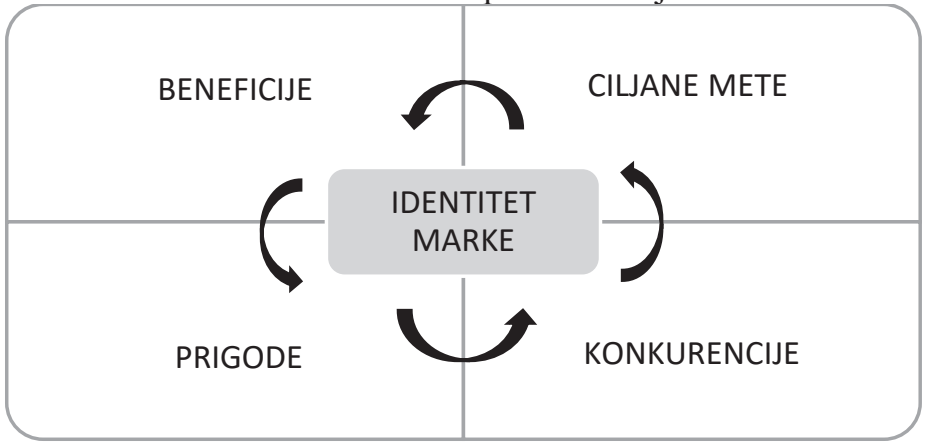

Izvor: Autori

Identitet možemo analizirati i kao primarnu etapu upravljanja markom jer automatski omogućuje uspostavljanje odnosa s markom. Sukladno tome, marka daje uslugama značenje i svrhu, ona postaje semiotski znak, šifra koju potrošači trebaju dekodirati. Poruka marke je vanjski izraz unutarnje esencije marke (Kapferer, 2008:177). Identitet izražava opipljive i nematerijalne karakteristike marke. Međutim, kao što je vidljivo iz Slike 1, marku možemo pozicionirati kao asocijativnu ili diferencijalnu, ali ona u svojoj esenciji nikada nije produkt samo jedne ili dvije značajke. Zbog toga se navode ciklički povezane četiri karakteristike koje se međusobno nadograđuju i čine marku cjelovitom strukturom. Zapravo, bit marke je ono što marka predstavlja u svom korijenu.

Upravljanje identitetom marke pretpostavlja prenošenje značajki na marku tijekom vremena. Esencija marke stoga se može promatrati dijakronijski i sinkronijski. Esencija marke podrazumijeva on što marka predstavlja u svojim korijenima, svoju genetsku strukturu (Govindarajan \& Trimble, 2005:47-76) koja se prenosi kroz vrijeme i prostor. Ona se može izgraditi kroz vrijeme, nije u startu strogo definirana. Zbog toga se kaže da je marka živi organizam koji se razvija kroz prostor i vrijeme. Sinkronijski gledano, esencija marke treba biti izravno povezan s misijom poduzeća. Razumijevanje značajki marki određuje na koji će se način dalje razvijati marka. DNK marke je samo privremeno zaustavljeno stanje stalne marketinške promjene. Međutim, znači li to da je esencija marke, dakle njen genom, nepredočiv individualnoj svijesti potrošača?

Ako je takav koncept jedinstveni sustav individualnih opažanja potrošača prema sinkorniji hijerarhijski uobličen u potrošačevu percepciju putem zajedničkog imidža, tada potrošači razabiru vrijednosti marke i prije njenog označavanja. Također, esencija marke postaje svojevrsna vrijednosna projekcija. Međutim, vrijednosnu projekciju čine potrošačeve percepcije, odnosno, u tom slučaju identitet je neodvojiv od imidža i jedan drugog uvjetuju. Stoga možemo zaključiti da je marka dinamična kategorija, metaforični živi organizam, koji jednom kreiran od strane pošiljatelja poruke, proživljava vlastitu renesansu. No, marka je ujedno i složen simbol koji može imati nekoliko značenja (Kotler et al, 2004:559). Tu se ponajprije misli na svojstva, korist, vrijednost i osobnost. Značajke marke stoga promatramo kao vezivno tkivo same biti marke, a elemente identiteta (Keller 
et al, 2008:165; Kapferer, 2008: 182-191) shvaćamo kao pomagala za identifikaciju i diferencijaciju od drugih konkurentnih marki.

Kako bismo to zornije prikazali, upotrijebimo model heksagonskog identiteta marke. Prema Kapfereru (2008: 183), identitet marke prikazan je kroz šest strukturiranih faseta. Sadržaj jedne fasete reflektira se na sadržaju druge. To znači da marka može egzistirati jedino ako svih šest dijelova identiteta međusobno komuniciraju. Lijeva strana heksagonske prizme prikazuje vidljive iskaze, a desna, unutarnje, manje vidljive iskaze marke. Prizma identiteta marke metaforički simbolizira heksagonski dijamant koji se sastoji od šest karakteristika identiteta marke. Najprije započinje fizičkim značajkama koje shvaćamo kao opipljive vrijednosti, tj. razvijanje identiteta, a završava samopredodžbom potrošača koja predstavlja emotivne i racionalne impresije (Cheverton, 2006: 9-23). Prvi korak u kreiranju marke je definiranje fizičkih značajki. One su na strani pošiljatelja marke i pripadaju u vidljive, opipljive elemente identiteta. Osobnost marke nalazi se na strani neopipljivih elemenata.

Pojam osobnosti marke proizlazi iz konstrukta ponašanja potrošača prema markama (Aaker, 1997: 347-356), a definira se kao set ljudskih karakteristika asociranih s markom. Osobnost marke (Aaker, 1996:142-151) polazi od hipoteze da potrošač marku percipira kroz personificiranost ljudskih osobina. Odnos s markom predstavlja simboličku razinu marke. To su metafore koje označuju specifične usluge i iznimno su subjektivne i varijabilne. Marka kao odraz označava da potrošači koriste marku kako bi izgradile vlastitu predodžbu. Ovdje je riječ o samoiskazivanju potrošača prema drugima. Konačno, marka je povezana i sa samopredodžbom. Samopredodžba je na strani primatelja i predstavlja isključivo perceptivni fenomen.

Identitet marke obuhvaća, najjednostavnije rečeno, sve ono čime poduzeće komunicira (Aaker \& Joachimsthaler, 2000:52) ili u kontekstu kreiranja imidža, sve značajke koje su asocijativne u potrošačevoj svijesti. Samim time, marka predstavlja komplementarni dio označavanja proizvoda koji je značajan čimbenik u kreiranju i održavanju imidža proizvoda. Svi elementi identiteta marke mogu poslužiti kao oblik uspješne komunikacije (Keller et al, 2008:142-146), pa tako i kao oblik poticanja za promjene u marketinškoj komunikaciji. Komunikacija marke je njena najvažnija tvorevina, bez komunikacije marka odumire.

\section{DEKONSTRUKCIJA IMIDŽA MARKE}

Izgradnja elemenata identiteta marke predstavlja početak kreiranja imidža. Imidž se oblikuje pod utjecajem različitih faktora koji su izvan kontrole poduzeća i mogu se, ali ne moraju, poklapati sa slikom koju poduzeće želi imati na tržištu (Pavičić et al, 2014:241). Promidžbene poruke, slogani, specifičan način ponašanja zaposlenika, vizualni/auditivni elementi tvore simbol. Međutim, simbol kao takav oblik potrošačevih percepcija ovdje ćemo shvaćati kao medij za priopćavanje imidža. Pojam simbola u marketingu, preciznije simbola kao imidža marke (Rocco, 2000:61; Karpati, 2001:124; Previšić, 2001:279; Kesić, 2003:113; Meler, 2005:193) često se shvaća kao sinonim pojmu znaka (Kotler \& Pfoertsch, 2006; Kotler \& Keller, 2008; Keller, 2002; de 
Chernatony, 2010) u smislu da nešto što je prisutno spontano priziva odsutni pojam. Simbol u teoriji marke shvaćamo kao konotativni znak sa "semantičkim viškom" nad označiteljem. To znači da izražajni imidž (simbol) izaziva prepoznavanje marke na osnovu bilo kojeg jezično motiviranog elemenata identiteta. Stoga, imidž možemo definirati kao mentalnu sliku. To je cjeloviti psihološki konstrukt dosadašnjeg iskustva, predodžbi, stavova, mišljenja, predrasuda, što pojedinac ili grupa formira (Sudar \& Keller, 1991:47).

Marka je razlikovna vrsta (Sudar \& Keller, 1991:47). Sama jezgra identiteta marke predstavlja esenciju marke pa su stoga njene jedinstvene i posebne vrijednosti, uvjetno rečeno, "utkane" u marku. Imidž marke reflektira trenutnu percepciju marke, stoga obuhvaća tri razlikovna komunikacijska obilježja (Aaker, 1996:180): (1) proširen imidž; (2) pojačan i iskorišten imidž; (3) mekan i raširen imidž. Proširen imidž predstavlja situaciju kada se identitet marke ne poklapa s imidžem marke, što je najčešće slučaj u demografskoj segmentaciji. Za razliku od proširenog imidža, pojačani i iskorišteni imidž obuhvaća određene dodane asocijacije koje potrošači razvijaju. Međutim, sam imidž marke ne treba određivati poziciju na tržištu. Pojačani imidž u svrsi je poboljšanja osobnosti marke (Aaker, 1997:347-357). Mekani i rašireni imidž zapravo je suprotnost pojačanom i iskorištenom imidžu. To su pojave miješanja segmenata potrošača koje prikazuju kako imidž marke nije uvijek dobro integriran u marketinškoj komunikaciji. Takvo premještanje kategorija potrošača zapravo je uobičajeno, jer su se trendovi potrošača promijenili pa se sukladno tomu i imidži marke moraju prilagođavati.

Imidž je rezultat komunikacijskog procesa, a sama komunikacija ima pozitivan učinak na preferenciju marke (Keller, 1987: 316-333). Riječ je o podražajnom stimulansu koji formira mentalnu sliku. Slika objekta formira se tek misaonim procesuiranjem (percepcijom). Imidž marke možemo promatrati kao sliku, predodžbu ili kompleksni doživljaj, tj. strukturu stavova, iskustva i uvjerenja prema proizvodu ili usluzi. Imidž je nedvojbeno psihološki integrirani konstrukt. Strategija razvijanja snage marke započinje jasnim razumijevanjem identiteta i imidža marke (Jukić, 2016:51-53). Kako bi izgradili tržišnu vrijednost marke, ključne su tri komponente od moguće četiri koje Aaker navodi u svom modelu pozicioniranja marke (Aaker, 1996:184): identitet, imidž i točke marke. Ono od čega polazi izgradnja snage marke upravo su potrošačeve misli o markama, njihove pozitivne konotacije, asocijacije, metafore i simboli.

Neki autori navode drugačije izraze (Kotler et al, 2004:282), poput variranja selektivne percepcije, selektivne iskrivljenosti pa sve do selektivnog pamćenja, što je u biti drugi aspekt promatranja modela asocijativnih mreža (Anderson, 1983:18). Pozitivan imidž marke stvara snažne i jedinstvene asocijacije u potrošačevoj memoriji. Što su snažnije emotivne impresije, asocijacije, snažnija je potrošačeva vjernost prema markama. Imidž marke usko je povezan s asocijacijama koje su svojevrsni "nositelji“ snage marke, pa se asocijacije promatraju zajedno s imidžem. Imidž se nalazi u svijesti potrošača (Kesić, 2003:116). Problem svijesti je kombinacija mentalnih modela, tzv. slike objekta i osjećaja samospoznaje (Damasio, 2005:22). Mentalne modele, tj. slike objekta, razlučujemo kao objekte koji ovdje predstavljaju marku, dok slike predstavljaju osjetne modalitete, tj. elemente marke (Jukić, 2019b:515). Te slike prenose različite vidove 
fizičkih svojstava (Kapferer, 2008) objekta, ali i emotivnu reakciju (Oatley \& Jenkins, 2007) potrošača.

Evidentno je da je emotivna komponenta imidža psihološka (Sudar \& Keller, 1991:50). Ako preokrenemo paradigmu imidža, tada imidž, u kontekstu integrirane marketinške komunikacije, shvaćamo kao nadređen pojam. Imidž je kreator identiteta jer je samo stvaranje marke pod utjecajem impresija. Iz prethodnog možemo zaključiti kako je imidž sastavni dio očekivane vrijednosti koju potrošači priželjkuju. Imidž je dodana vrijednost marke i odražava konkurentsku prednost spram drugih marki. Poduzeće kao izvor i komunikator predodžbi marke svojim odnosom (Govoni, 2004:183) s potrošačima nastoji pronaći najoptimalniji put do primatelja poruke. Slika 2. prikazuje konceptualni model imidža marke usluge.

Slika 2. Sadržaj imidža marke usluge

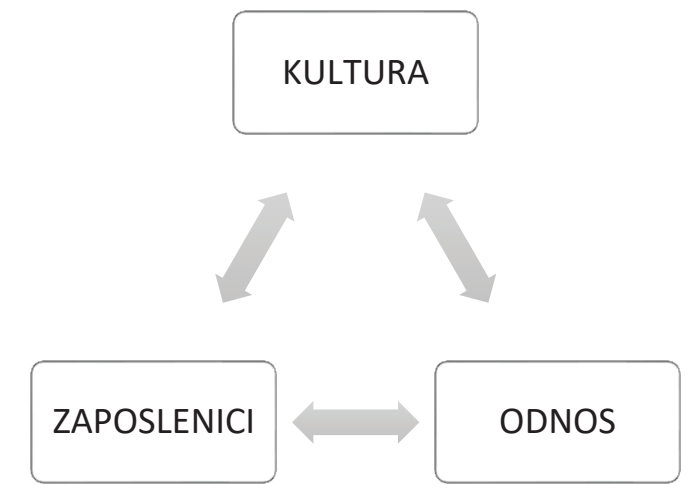

Izvor: Autori

Kao što je vidljivo, imidž je ključno sredstvo komuniciranja s potrošačima pa samim time i ključni pojam u marketingu. Kada govorimo o strategiji upravljanja imidžem, najprije moramo raščlaniti imidž na sadržaj: (1) kulturu poduzeća; (2) zaposlenike; (3) odnos s kupcima. U segmentu marke usluge, imidž komunicira sa zaposlenicima s ciljem učvršćivanja vlastite predodžbe o sebi kao članu zajednice. Sama kultura poduzeća također obuhvaća zaposlenikov odnos prema kupcima kao i povjerenje na kojem se u konačnici grade odnosi s potrošačima. Međutim, imidž možemo promatrati i kroz tri dimenzije (Kesić, 2003:112): kao objekt - proizvod, obilježje proizvoda i subjekt - proizvod. Objekt proizvod tada je apstraktni pojam i predstavlja idealizirani imidž koji služi samo za uspoređivanje. Obilježja proizvoda obuhvaćaju percipirane svojstva i ona predstavljaju budući imidž proizvoda. Subjekt proizvoda predstavlja ciljne skupine, a polazi od psiholoških koristi. Dakle, vidljivo je kako je riječ o potrošačevim asocijacijama koje su povezane s psihičkim i fizičkim obilježjima marke.

Imidž ne uspoređujemo s vanjskom realnošću jer za njega ne postoje činjenice, postoje samo filtrirane poruke (Sudar \& Keller, 1991:49). U konačnici, to je ujedno 
prednost i mana imidža, to je rezultat interakcije svih iskustava, vjerovanja i impresija. Takva sveukupnost, slika, percepcija, ideja i predodžbi osnovni je postulat proučavanja potrošačeva odnosa s markom. Set asocijacija koje marka pobuđuje kod potrošača pripada u sferu imaginarnog, barem što se tiče analitičko-deduktivne konstrukcije. Imidž polazi od korijena imaginacije, teorije mita i psihološkog konstrukta samopredodžbe. U takvom intelektualno emocionalnom doživljaju imidž raščlanjujemo u dvije kategorije: psihološku i antropološku.

Identitet marke kao kauzalni, prvostvoreni model, predstavlja vlastitu kreaciju i on kao takav predstavlja ono vidljivo, opipljivo, ono što prenosi stvaranje. Međutim, imidž je posljedica te kreacije, imidž je ono u što potrošač vjeruje, i to je ključna dihotomija. Na identitet možemo utjecati, no vrlo teško možemo empirijski valorizirati, utjecati ili strogo definirati parametre imidža kao doživljaja. Uostalom, percepcija marke usluge vrlo je subjektivna (Ozretić Došen, 2001: 443) i upravo zbog te "neuhvatljivosti" istu uslugu ista osoba može drugačije doživjeti unutar samo sat vremena.

Imidž promatramo sukladno komunikacijskim porukama, tj. znaku sporazumijevanja kao dihotomni konstrukt imaginarnog i emotivnog. Imaginarno ulazi u sferu teorije mita jer imidž marke ima karakteristike imaginarnog, kreiranog vjerovanja. Konačno, je li imidž marke doista preuzeo neke karakteristike iz teorije mita? Mit je bio predmet različitih pristupa u suvremenim društveno-humanističkim znanostima. Arhetipska kritika na tragu psihoanalize (Jung, 1981), shvaća mit kao vrstu sižea koji egzistira kroz povijest u obliku fabularnog obrasca. Budući da je nalik obredu, kao marka kulta (Jukić, 2018:431-434), mit shvaćamo kao imaginarnu strukturu. Ključ za razumijevanje jungovskog pristupa mitologiji leži u konceptu slike (Walker, 2002:3). No, upravo zbog te apstraktnosti obrazaca, mit se konkretizira u različitim formama, što omogućuje postmoderno tumačenje marke kao simbola. Takav imidž naziva se iskonska slika kada posjeduje "iskonski karakter". To znači da je arhetip mita kolektivan. Arhetipski motivi imidža marke, s aspekta marketinga, doista jesu marke kulta. Uostalom, čak i konstrukt osobnosti marke polazi od određenih arhetipova.

Mitovi stoga nisu spontani proizvodi psihe već su kulturno razrađeni (Walker, 2002:4). Drugi način poimanja mita i imidža marke je u kontekstu antropologije intervarijantnosti mita (Levi-Strauss, 2001; Levi-Strauss, 2013; Levi-Strauss, 2014). Elementi mitske misli uvijek su na pola puta između osjetilnih i znanstvenih pojmova. To automatski znači da Levi-Strauss (2001) postavlja mit na raspolaganje u polivalentnu građu. Konkretno, mit dobiva ulogu operatora reorganizacije dvije kategorije kao medijator koji transformacijom binarnih oprjeka tumači simboliku mita. Kada mit tumačimo na arhetipski način tada određena osobnost marke snažno aludira na percepciju potrošača, na kolektivnu svijest. Marketinškom komunikacijom oblikujemo poruku (siže mita) služeći se elementima identiteta marke. S druge pak strane, potrošači tumače mitsku strukturu u skladu s demografskim, kulturnim i psiho-socijalnim karakteristikama.

Potrošači odabiru proizvode koji su sukladni njihovim slikama o sebi, a odbacuju one koje su u nesuglasju. Budući da kupljeni proizvod utječe na formiranje slike o potrošaču (Foxall et al, 2007:55), navedena hipoteza služi kao jedna od uloga potrošačevih impresija. Međutim, pojam samopredodžbe također možemo promatrati s 
aspekta životnih stilova potrošača, budući da se samopredodžba shvaća kao sveukupnost potrošačevih misli, osjećaja i vrijednosti koje su upućene prema sebi kao objektu.

Zanimljivo je da samopredodžba, budući da je perceptivna kategorija, ne mora nužno biti realna, kao što nisu ni slike marke pokazatelji stvarne vrijednost marke. To znači da potrošači zapravo procjenjuju svoja iskustva u odnosu na samopredodžbu, ali i u odnosu na iskustva s markom. Trajne slike o sebi potrošači projiciraju kroz marke koje se podudaraju s njihovom samopredodžbom (Kesić, 2003:118). To znači da se, ako se imidž marke podudara s imidžom potrošača, stvara preduvjet vjernosti prema markama. U biti, potrošači teže odraziti svoju samopredodžbu kroz marke (Schiffman \& Kanuk, 2004:111). Samopredodžbu potrošača kao svojevrstan autoportret shvaćamo kao određeno znanje koje potrošač ima o vlastitim karakteristikama i sposobnostima (Laird, 2007:183-204). Potrošačeva svjesnost označava razmišljanja o vlastitosti pa se može promatrati kao subjekt (svijest o sebi) i kao objekt spoznaje (pojam o sebi). Marka stoga postaje potrošačeva predodžba koja komunicira na simboličkoj razini, a ujedno predstavlja aktivnu sliku potrošačeve samopredodžbe.

\section{DOŽIVLJENA KVALITETA USLUGE}

Marka je nematerijalno dobro koje ima snagu stvarati financijske prihode (Predovic, 2007:7) koji se vremenom mogu pretvoriti u značajnu vrijednost poduzeća te tako jamčiti održivu konkurentsku prednost na tržištu. Vrijednost marke možemo promatrati s dva aspekta: aspekta poduzeća i aspekta potrošača. Promatrajući marku kroz prizmu poduzeća, marka predstavlja određenu vrijednost u koju se ulaže i kojom se upravlja. Sukladno tome, marka je imovina, jer proizvođač ima pravo vlasništva koje se može prenositi, prodavati i registrirati. Međutim, promatrajući marku s aspekta potrošača, marka predstavlja simbol koji se izgrađuje impresijama, asocijacijama, metaforama, osobnošću i dodanom vrijednošću. Uloga komponenti usluga u odnosima s kupcima smatra se strateškom (Grönroos, 2007a: 6). Značenje marke u sektoru usluga je izuzetno jer marka informira korisnika o ujednačenosti kvalitete (Ozretić Došen, 2002:145). Bez obzira je li uloga kupca u procesu usluživanja aktivna ili pasivna, prisustvo kupca na mjestu pružanja usluga predstavlja najznačajniju specifičnost marketinga usluga. Neopipljivost usluga najčešće se navodi kao najvažnija specifičnost (Grönroos, 2000:4557; Ozretić Došen, 2001: 429-450; Ljubojević, 2002:21-39; Ozretić Došen, 2002:25-29; Grönroos, 2007a:51-64; Andreasen \& Kotler, 2008:197-206; Sargeant, 2009:180-191; Veljković, 2009:102-122; Babić-Hodović, 2010:45-72), no iz pomnije analize proizlazi da je osnovna karakteristika usluga upravo prisustvo kupca na mjestu pružanja usluga.

Analiziranje specifičnosti usluga promatramo od posljednje navedene komponente (Babić-Hodović, 2010:47), tj. prisustva kupca na mjestu pružanja usluga iz koje će posredno utjecati na odnos s markom (Grönroos, 2007a:331). Osim kupca, prisutni su i drugi potencijalni korisnici, što dodatno otežava kreiranje iskustva i mogućnost upravljanja kontrole usluge. To znači da "zajedničko iskustvo" može biti pozitivno ili negativno pa čak ni kada nema drugih korisnika usluge. Konkretno, u marketingu kazališta (Jukić, 2018:420-445), kada samo odsustvo korisnika utječe na negativnu 
percepciju aktualnih korisnika. Međutim, vrijedi i obrnuto. Ako traženje usluge nadilazi maksimalne raspoložive kapacitete za pružanje usluga, potrošači će se orijentirati konkurenciji zbog "frustracije“" (Egan, 2004:110) čekanja usluge.

Kreiranje marke danas je nadmašilo osnove marketinške promocijske aktivnosti i postalo svojstveno stilu, kultu i filozofiji življenja. Stilu, jer se marka revitalizira modom i raznim utjecajem vraća, upravo poput avangardne umjetnosti. Njihova stilska karakteristika usko je vezana uz društvene, kulturne i socijalne okolnosti. Kult, jer se marka ponaša poput mita, a mit živi dok korisnici u njega vjeruju. I konačno, kao filozofija življenja, jer marka ujedinjuje stil, epohu, kult, mit i način života. Marke su protkane u svim društvenim sferama te postaju, ne samo diferencijacija, već i jezični znak postmodernog društva. Marka usluge znači bezuvjetno obećanje buduće satisfakcije korisnika (Berry, 2000:128-137). Ključna razlika između marke proizvoda i marke usluga, osim u evidentnoj naravi samih elemenata usluge, svakako su dvije dimenzije od presudne važnosti: uloga zaposlenika i iskustvo potrošača.

Uloga zaposlenika je neupitna. Zaposlenici predstavljaju izuzetno važan element marketinškog miksa u uslužnim organizacijama (Rajh \& Ozretić Došen, 2009:69-83) i često se naziva "moć ljudi“ (Judd, 2003:1301-1313). Uloga zaposlenika u uslužnim organizacijama ovisi prvenstveno od vrste usluge koja se pruža i učešća koje zaposlenici imaju u procesu usluživanja. Imidž svakog uslužnog poduzeća u javnosti ponajviše stvaraju zaposlenici koji dolaze u kontakt s korisnicima usluga (Ozretić Došen, 2002:121). Njihova interakcija je dvostruka, s vanjskim okruženjem i unutarnjom strukturom. Zaposlenici marke usluge imaju dvije uloge (Hoffman \& Bateson,1997:239): transfer informacija i prezentacija poduzeća. Transfer informacija znači da zaposlenici trebaju pružiti kupcima informacije o novim vrstama i tipovima usluga, a prezentacija poduzeća označava izgradnju imidža marke kroz pozitivne odnose s markom.

Ako se tvrdi da je marka povezana s misijom poduzeća tada zaposlenici moraju dijeliti istu viziju marke i njene zajedničke vrijednosti. Zaposlenici moraju vjerovati u marku i njene vrijednosti (Ozretić Došen, 2002:121), oni su promotori marke usluge i njeni sukreatori. Ako zaposlenici ne vjeruju u marku, tada je njena svrha besmislena (Babić-Hodović, 2010:546). Upravo zbog navedenog, bitno je vjerovanje marki i njegovanje svih vrijednosti marke (Aaker, 1991:16-17). Da bi se ostvarila takva učinkovitost komuniciranja, važan je identitet marke. Najvažnije značenje marke usluge su njezine osobnosti. Markama se ne upravlja oglašavanjem, već iskustvom marke (Kotler et al, 2004:567).

Ujedno, svi su ti kontakti varijabilni, jer bilo koji kontakt može biti pozitivna ili negativna potrošačeva impresija. Upravo zbog navedenog, poduzeće mora ulagati znatan napor u svoje zaposlenike (Ozretić Došen, 2002:124; Babić-Hodović, 2010:546-549) jer su oni ogledalo marke. Zadovoljstvo zaposlenika i zadovoljstvo potrošača jasno su povezani (Hoffman and Bateson, 2011:229). Zanimljivo je da marka usluge ima znatno važniju ulogu za potencijalne potrošače nego predstojeće. Budućim potrošačima marka usluge pomaže da smanje percipirani rizik predkupovne faze. Postojećim potrošačima mnogo je važnija potvrda danih obećanja. Kada analiziramo marku usluge, mi zapravo promatramo tri kategorije koje određuju prisutnost marke u svijetu kupca (Berry, 2000:128-137). poznatost marke, značenje marke i identitet marke. 
Poznatost marke predstavlja sposobnost potrošača da prepozna marku na određeni poticaj, koji se s aspekta upravljanja markom utemeljenoj na tržišnoj vrijednosti promatra kao odjek marke (Keller et al, 2008:57). Značenje marke shvaća se u smislu prvih asocijacija na marku koja se stvara kroz informacije koje je potrošač prikupio. I konačno, identitet marke ovdje se promatra kao rezultat percepcije poduzeća. U biti, poznatost marke analogna je s modelom upravljanja markom utemeljenoj na tržišnoj vrijednosti (Keller et al, 2008:42-88). Također, prisjećanje marke prvi je stupanj prepoznavanja marke (Aaker, 1996:10-17; de Chernatony \& McDonald, 2003:47; Kapferer, 2008: 188-197; Keller et al, 2008:54-58). Posljednja kategorija marke usluge u svijesti potrošača (Berry, 2000:128-137) predstavlja značenje marke koje je prikaz pozitivnih potrošačevih impresija, što nas dovodi do heksagonske prizme identiteta (Kapferer, 2008:183). Međutim, identitet ovdje možemo promatrati kao imidž poduzeća, ili shvaćajući ga još šire, kao identitet poduzeća (Balmer, 2001:248-291; Balmer \& Gray, 2003: 972-997; Urde, 2003:1017-1040) marke usluge.

Pozicioniranje marke neće u potpunosti uspjeti ako svaki zaposlenike tvrtke ne bude promicao marku. Poduzeća koje provode unutrašnje kreiranje marke pomažu zaposlenicima da jasnije razumiju obećanje marke (Tosti \& Stotz, 2001:29-33). Uz interne komunikacije, koje organizira poduzeće marke usluge, potrebno je navesti simultano postojanje eksternih komunikacija i iskustva potrošača. Eksterne komunikacije rezultat su usmene propagande i one nisu pod kontrolom poduzeća. Iskustvo potrošača nastaje kao rezultat korištenja usluge. Dakle, možemo zaključiti da prezentiranje marke direktno utječe na poznatost marke, a iskustvo potrošača na značenje marke usluge. Eksterna komunikacija može kreirati indirektan utjecaj usluge marke, dok interna komunikacija utječe na prezentiranje marke. U trećoj fazi, poznatost marke i značenje utječu na kreiranje identiteta marke. Pri tome, direktan je utjecaj značenje marke, a indirektni utjecaj poznatost marke usluge. Iz navedenog zaključujemo kako marka usluge ima identitet samo za one potrošače koji su koristili uslugu, tj. koji imaju iskustvenu komponentu. To znači da one usluge i ona poduzeća koja imaju visok nivo poznatosti na tržištu, ali ne i dovoljan nivo isprobavanja i korištenja od strane potrošača, ne mogu govoriti o izgrađenom identitetu usluge (Babić-Hodović, 2010:361).

Pojam doživljene kvalitete predstavlja konceptualni model koji inkorporira kvalitetu usluge, ali se proteže i na aspekte korisničkog iskustva koje nije toliko direktno povezan sa samom uslugom koliko s markom (Klaus \& Maklan, 2007:115-122). Prilikom praćenja kvalitete usluge (Grönroos, 1984:36-41) potrebno je voditi računa o interakciji s potrošačima jer je njihovo iskustvo s uslugom ključno prilikom formiranja impresija. Stoga se uloga zaposlenika nameće kao najvažnija prilikom strategije kreiranja identiteta poduzeća, jer su upravo zaposlenici nositelji cijelog procesa, oni su marka zaposlenika (Hoffman \& Bateson, 2011:239). Svaki kontakt s potrošačem, iskustvo potrošnje i komunikacija stvara iskustvo u umu potrošača. (Klaus \& Maklan, 2007:119). Doživljena kvaliteta obuhvaća faktore kao što su: pozitivan stav zaposlenika, atmosferu poduzeća, ugodni ambijent i osobni kontakt s potrošačima. Usredotočenost na korisničko iskustvo, umjesto same usluge, potaknut će menadžere marki da dublje i značajnije shvate vrijednost koju kupci pronalaze iz njihove ponude (Klaus \& Maklan, 2007:120). 
Prvo uslužno iskustvo možemo promatrati kao početni stadij kontakta s uslugom na osnovi kojeg potrošači formiraju mišljenja. Pozitivna mišljenja potvrdit će iskustvo u uslužnoj interakciji, a kao rezultat, formirat će se povjerenje u poduzeće. Vrijedi i obrnuto. Negativna iskustva formiraju nepovjerenje u poduzeće i marku koji pokušavamo izgraditi. To znači da za potrošače mnogo veći utjecaj ima vlastito iskustvo u formiranju značenja marke, a indirektni utjecaj predstavlja prezentaciju marke. Usluge su same po sebi relacijske (Grönroos, 2007a: 8). Drugim riječima, identitet usluge gradi se kod kupaca koji su koristili marku usluge. To je ujedno i odgovor zašto se zadovoljstvo najčešće formira prema poduzeću, a vrlo rijetko prema konkretnoj usluzi. Stoga se javlja paradoks u procesu gradnje usluge. Potrošači veću pažnju poklanjaju procesu pružanja usluge, a ne samoj usluzi. Uostalom, često je nemoguće odvojiti percepciju usluge od ukupne percepcije pružatelja usluge.

Uloga doživljene kvalitete marke usluge polazi od dva elementa: zadovoljstva (subjektivne kategorije očekivane vrijednosti) i zajedništva (uloga marke poduzeća). Potrošači uspostavljaju odnos s markom na temelju pozitivnog iskustva. Zbog toga se razumijevanje marke i mijenja u trenutku kada potrošači preuzimaju aktivnu ulogu. To je proces koji se razvija s potrošačima. Također, prema procesu građenja marke usluge (Berry, 2000:128-137) ne mogu se odvojiti dijelovi uslužnog sistema. Diferenciranje je prvi korak, a on se temelji na pružanju jedinstvene usluge. Građenje vlastite poznatosti i kreiranje emocionalnih veza (Gobe, 2001:121-158) paralelno se radi na izgradnji imidža i na bazi iskustva kupca s markom. Konačno, internaliziranje marke aludira na ulogu zaposlenika koja nas opet vraća na početak, pod uvjetom da je ta uloga zaposlenika realna.

Poduzeća moraju graditi emocionalne veze s potrošačima (Grönroos, 2004:99113). Dakako, izgradnja identiteta marke u svijesti zaposlenika također mora biti zasnovana na snažnoj emotivnoj vezi. Odnos zaposlenika prema markama usluge i njihova uloga u građenju iznimno su važni u uslugama visokog kontakta, tj. kada je fokus na samom korisniku. To znači da uslužna marka postaje snažna u istoj mjeri koliko su snažni zaposlenici (Berry \& Lampo, 2004:18-25). Emocionalna povezanost bazira se na činjenici da se usluge mogu pružati samo ako postoji emocionalna veza s kupcima. Takve marke kreiraju personalizirano iskustvo i u konačnici grade povezanost i bliskost.

\section{ZAKLJUČAK}

Odnos s markom razvija se u svijesti potrošača kroz korelaciju iskustva, imidža i identiteta marke. Odnos s markom razvija se u nizu kontakta s markom koju je iskusio kupac (Schultz \& Barnes, 1999:46). U tom kontekstu, kontakt s markom shvaćamo kao imidž i iskustvo kupca koje nosi informaciju. Dakle, kontakt s markom formira njen odnos. Taj odnos može biti različit jer ovisi o vrsti kontakta, ali ujedno može buditi pozitivne i negativne impresije potrošača. Potrošač kontinuirano održava stalne veze s markom (Grönroos, 2007a:332). Sukladno iskustvu kontakta (Schultz \& Barnes, 1999:35-56), možemo govoriti o različitim tipovima iskustva s markom. Sam pojam kontakta s markom ovdje shvaćamo kao proces vrednovanja marke (Grönroos, 
2007a:333). Konkretno, pojam vrednovanja marke označava kontakt koji ujedinjuje potrošačevu percepciju koliko mu je dragocjena pružena usluga.

To znači da će s vremenom, ako proces vrijednost marke opada, potrošač biti skloniji drugim rješenjima i komunikaciji s konkurencijom. Naravno, ako se vrijednost marke poveća, veća je vjerojatnost da će potrošač ostati vjeran. To nas vraća na analizu identiteta jer identitet marke shvaćamo kao viziju iza koje se nalazi marka sa svojim vrijednostima, obećanom koristi i jedinstvenošću na koju će reagirati potrošač. S aspekta vjernosti markama, privrženost možemo promatrati kao jedan, uvjetno rečeno, oblik potrošačkog odnosa. Istraživanja u marketingu potvrđuju pretpostavku da potrošači mogu razviti određeni oblik privrženosti prema markama (Park et al, 2008:2). Takvim slijedom, privrženost tumačimo kao privrženost objektu, jer potrošača promatramo s perspektive potrošačeva odnosa prema markama. Privrženost označava potrošačeve emocionalne i racionalne impresije prema markama, odnosno stanje uma. Takvo shvaćanje dovodi nas do pojma samopredodžbe. Privrženi objekt postaje povezan sa samopredodžbom potrošača, što zapravo aludira na potrošačevu percepciju.

Da bi potrošači dobili željenu vrijednost marke usluge, poduzeća moraju razviti interakcije s kupcima (Lindberg-Repo \& Grönroos, 2004: 229-239; Grönroos, 2009:351359). Dakako, interakcije polaze od iznimno značajne uloge zaposlenika, ali ne formalne (Sikula, 2001:419-428), već doista sadržajne, istinske usluge. Pravi, istinski odnos između marke poduzeća i potrošača ne postoji (Grönroos, 2007b:194). Postojanje odnosa s markom usluge je latentno. Ono u biti postoji, ali nije u svojoj punini i uvijek je na granici između relacijskog i transakcijskog modela. Kako bi se postigla relacija između potrošača i marke usluge, mora postojati treća razina marke poduzeća, a to je da se zaposlenici povezuju s organizacijom.

Za postojanje marke usluge poduzeća mora biti uslužno orijentirana. Usluga neće dugoročno opstati na tržištu, ako ne bude orijentiran na odnos s markom. Usluga, bez obzira je li hibridna, potpuna ili kao prateća, uz postojeću marku ne može uspješno egzistirati ako je samoj sebi svrha. Usluga postoji zbog odnosa s potrošačem. Potrošač definira, nagrađuje, i u konačnici, kažnjava uslugu. Uostalom, ako itko stvara marku, to je potrošač (Grönroos, 2007a:331). Pružanje usluge stoga možemo promatrati kao jezgrenu vrijednost marke (Grönroos, 1990:6-14), a odnos s potrošačima, u tom je kontekstu dodana vrijednost.

Također, netočan je sam pojam izgradnje marke (Grönroos, 2007a:334), jer implicira da možemo kreirati marku. Marka se stvara u potrošačevim impresijama i ona slijedi ugovor s markom koji predstavlja interakciju između zaposlenika i potrošača. Zbog toga je uloga zaposlenika iznimno važna jer su oni nositelji vizije marke, uvjetno rečeno, "zaposlenik marka" (Hoffman and Bateson, 2011:239). Međutim, tu je odgovornost dvostruka: uloga identiteta poduzeća odražava se na zaposlenicima i ona mora biti dvosmjerna. Sama kultura poduzeća također obuhvaća zaposlenikov odnos prema kupcima, kao i povjerenje na kojem se grade odnosi s potrošačima.

Buduća istraživanja s aspekta fenomenologije identiteta marke, trebala bi biti usmjerena na pojedinačnu analizu elementa identiteta marke usluge. To se ponajviše odnosi na raščlambu heksagonske prizme identiteta prema Kapfererovoj teoriji koja se u marketingu prihvaća apriorno. Iako postoje istraživanja konstrukta osobnosti marke, 
nužno je učiniti i preostala istraživanja, kako na kvalitativnoj tako i na kvantitativnoj razini. Konkretno, psihološka istraživanja koja bi potvrdila ili opovrgnula teorije iznesene u ovom radu, a odnose se na samopredodžbu potrošača i izgradnju identiteta. Na taj način dobili bismo odgovore na pitanja zašto se potrošači i u kojoj mjeri identificiraju $s$ markama. Također, mogu se provesti istraživanja i s antropološkog aspekta u kojima bi se analizirao utjecaj mitske strukture na izgradnju identiteta marke. Takvim interdisciplinarnim pristupom možemo dobiti odgovor na pitanje što čini fenomen marke kulta.

\section{LITERATURA:}

1. Aaker, D. A. (1991) Managing Brand Equity. New York: Free Press

2. Aaker, D. A. (1996) Building Strong Brands. New York: Free Press

3. Aaker, D. A., Joachimsthaler, E. (2000) Brand Leadership. London: Pocket Books

4. Aaker, D. A. (2004) Brand Portfolio Strategy. New York: Free Press

5. Aaker, J. (1997) Dimensions of brand personality. Journal of Marketing Research, 34 (3), pp. 347-357

6. Acosta, P. M. Devasagayam, R. (2010) Brand Cult: Extending the notion of brand communities. Marketing Management Journal, 20 (1), pp. 165-176

7. Anderson, J. R. (1983) The Architecture of Cognition. Cambridge: Harvard University Press

8. Andreasen, A. R. Kotler, Ph. (2008) Strategic Marketing for Nonprofit Organizations, New Jersey: Pearson Education

9. Babić-Hodović, V. (2010) Marketing usluga, Sarajevo: Ekonomski fakultet u Sarajevu

10. Balmer, J. M. T. (2001) Corporate identity, corporate branding and corporate marketing, seeing through the fog. European Journal of Marketing, 35 (3/4), pp. 248-291

11. Balmer, J. M. T. Gray, E. R. (2003) Corporate brands: what are they? What of them? European Journal of Marketing, 37 (7-8), pp. 972-997

12. Baudrillard, J. (2017) Simulacra and Simulation. Michigan: University of Michigan Press

13. Bauman, Z. (2011) Tekuća modernost. Zagreb: Pelago

14. Belk, R. W. (1988) Possessions and extended self. Journal of Consumer Research, 15 (2), pp. 139-168

15. Belk, R. W. (2013) Extended self in a digital world. Journal of Consumer Research, 40 (3), pp. 477-500

16. Berry, L. L. (2000) Cultivating Service Brand Equity. Journal of the Academy of Marketing Science, 28 (1), pp. 128-137

17. Berry, L. L, Lampo, S.S. (2004) Branding Labour-Intensive Services. Business Strategy Review, 15 (1), pp.18-25

18. Cheverton, P. (2006) Understanding Brands. London: Kogan Page 
19. Damasio, A. (2005) Osjećaj zbivanja. Zagreb: Algoritam

20. de Chernatony, L. (2010) From Brand Vision to Brand Evaluation. Oxford: Butterworth-Heinemann

21. de Chernatony, L., McDonald, M.(2003) Creating powerful brands. Oxford: Butterworth-Heinemann

22. Egan, J. (2004) Relationship Marketing. London: Prentice Hall

23. Foxall, R. G. Goldsmith, R. E. Brown, S. (2007) Psihologija potrošnje u marketingu. Jastrebarsko: Slap

24. Gobe, M. (2001) Emotional Branding: The New Paradigm for Connecting Brands to People. New York: Allworth Press

25. Govindarajan, V. Trimble, C. (2005). Organizational DNA for Strategic Inovation. California Management Review, 47 (3), pp. 47-76

26. Govoni, N. A. (2004) Dictionary of Marketing Communications. London: Sage Publications

27. Grönroos, C. (1984). A service quality model and its marketing implications. European Journal of Marketing, 18 (4), pp. 36-44

28. Grönroos, C. (1990) Service management: a management focus for service competition. International Journal of Service Industry Management, 1 (1), pp. 6-14

29. Grönroos, C. (2000) Service Management and Marketing: A Customer Relationship Management Approach. Hoboken: John Wiley Sons

30. Grönroos, C. (2004) The relationship marketing process: Communication, interaction, dialogue, value. The Journal of Business \& Industrial Marketing, 19 (2), pp. 99-113

31. Grönroos, C. (2007a) Service Management and Marketing: Customer management in Servicce Competition. Hoboken: John Wiley Sons

32. Grönroos, C. (2007b), In Search of a New Logic for Marketing. Hoboken: John Wiley Sons

33. Grönroos, C. (2009) Marketing as promise management: regaining customer management for marketing. Journal of Business \& Industrial Marketing, 24 (5/6), pp. 351-359

34. Haig, M. (2004) Brand Royalty. London: Kogan Page

35. Hoffman, K. D. Bateson, E. G. J. (1997) Essentials of Service Marketing. Orlando: The Dryden Press

36. Hoffman, K. D. Bateson, E. G. J. (2011) Service Marketing: Concepts, Strategies \& Cases. Mason: South-Western Cengage Learning

37. Judd, C. V. (2003) Achieving a customer orientation using "people power", the "5th P". European Journal of Marketing, 37 (10), pp. 1301-1313

38. Jukić, D. (2016) Dekonstrukcija marke utemeljena na potrošaču. Zbornik radova (Journal of Economy and Business) Ekonomskog fakulteta Sveučilišta u Mostaru, 22 (1), pp. 49-76

39. Jukić, D. (2018) Dreams and Reality in Culture Marketing: Theatre Sphere. In: Solik, M., Rybansky, R. (Eds.), Megatrends and Media: Reality and Media 
Bubbles, Trnava: Faculty of Mass Media Communication, University of SS. Cyril and Methodius in Trnava, pp.420-445

40. Jukić, D. (2019a), Strategic Analysis of Corporate Marketing in Culture Management. International Journal of Strategic Management and Decision Support Systems in Strategic Management, 24 (1), pp. 10-18

41. Jukić, D. (2019b) Opening Pandora's Box: Neuromarketing and Brand Image. In: Ondra, P. (Ed), DOKBAT 2019 15th Annual International Bata Conference for Ph.D. students and Young Research, Zlin: Thomas Bata Univerity, Faculty of Management and Economics, pp.512-524

42. Jung, C. G. (1981) The Archetypes and the Collective Unconscious. Princeton University Press

43. Kapferer, J. N. (2001) Reinventing the brand. London: Kogan Page

44. Kapferer, J. N. (2008) The New Strategic Brand Management. London: Kogan Page

45. Karpati, T. (2001) Marketing $u$ dinamici. Osijek: Ekonomski fakultet u Osijeku

46. Keller, L., K. (1987) Memory Factors in Advertising: The Effects of Advertising Retrieval Clues on Brand Evolutions. Journal of Consumer Research, 14 (3), pp. 316-333

47. Keller, L. K. (2002) Strategic Brand Management. New Jersey: Prentice Hall

48. Keller, L. K., Aperia, T. Georgson, M. (2008) Strategic Brand Management. London: Pearson

49. Kesić, T. (2003) Integrirana marketinška komunikacija. Zagreb: Opinio

50. Klaus, P. Maklan, S. (2007) The role of brand in a service-dominated world. Brand Management, 15 (2), pp. 115-122

51. Kotler, Ph. Armstrong, J. Harris, L. C. Piercy, N. (2016) Principles of Marketing, New Jersey : Prentice Hall

52. Kotler, Ph. Keller, K. L. (2008) Marketing management. New York: Prentice Hall

53. Kotler, Ph. Pfoertsch, W. (2006) B2B Brand management. Berlin-Heidelberg: Springer

54. Kotler, Ph. Wong, V. Saunders, J. Armstrong, G. (2004) Principles of Marketing, New Jersey : Prentice Hall

55. Laird, D. J. (2007) Feelings: perception of self, Oxford: Oxford University Press

56. Levi-Strauss, C. (2013) Antropologija i moderni svijet. Zagreb: TIM press

57. Levi-Strauss, C. (2014) Svi smo mi kanibali. Zagreb: TIM press

58. Levi-Strauss, C. (2001) Divlja misao. Zagreb: Golden marketing

59. Lindberg-Repo, K. Grönroos, C. (2004) Conceptualising communications strategy from a relational perspective. Industrial Marketing Management, 33 (3), pp. 229-239

60. Ljubojević, Č (2002) Marketing usluga. Novi Sad: Stylos

61. Meler, M. (2005) Osnove marketinga. Osijek: Ekonomski fakultet u Osijeku

62. Oatley, K. Jenkins, J. M. (2007) Razumijevanje emocija. Jastrebarsko: Naklada Slap 
63. Ozretić Došen, Đ. (2001) Marketing usluga. In: Previšić, J. Bratko, S. (Eds), Marketing. Zagreb: Sinergija, pp. 429-450

64. Ozretić-Došen, Š. (2002) Osnove marketinga usluga. Zagreb: Mikrorad

65. Park, W. C. Maclnnis, J. D., Priester, J. (2008) Brand Atachment: Construct, Consequences and Causes. Hanover: Now Publishers

66. Pavičić, J. Gnjidić, V. Drašković, N (2014) Osnove strateškog marketinga. Zagreb: Školska knjiga

67. Prahalad, C. K. Ramaswamy, V. (2004) Co-Creation Experiences: The Next Practice in Value Creation. Journal of Interactive Marketing, 18 (3), pp.5-14

68. Predovic, D. (2007) Vrednovanje marke. Zagreb: MATE

69. Previšić, J. (2001) Proizvodi. In: Previšić, J. Bratko, S. (Eds), Marketing. Zagreb: Sinergija, pp. 277-308

70. Rajh, E. Ozretić Došen, Đ. (2009) The effects of marketing mix elements on service brand equity. Economic research/Ekonomska istraživanja, 22 (4), pp. 69-83

71. Rocco, F. (2000) Marketinško upravljanje. Zagreb: Školska knjiga

72. Sargeant, A. (2009) Marketing Management for Nonprofit Organizations. Oxford: Oxford University Press

73. Schiffman, L. G. Kanuk, L. L. (2004) Ponašanje potrošača. Zagreb: MATE

74. Schmidt, L. K. (2006) Understanding Hermeneutics. Stocksfield: Acumen Publishing Limited,

75. Schultz, D. E. Barnes, B. E. (1999) Strategic Brand Communication Campaigns. Chicago: Lincolnwood, NTC Business Books

76. Sikula, A. Sr. (2001) The five biggest HRM lies. Public Personnel Management, 30, (3), pp. 419-428

77. Smith, S. (2003) Brand experience. In: Clifton, R. Simmons, J. (Eds), Brands and branding, London: Profile Books, pp. 97-111

78. Sudar, J. Keller, G. (1991) Promocija. Zagreb: Informator

79. Tosti, D. T. Stotz, R. D. (2001) Building your brand from the inside out. Marketing Management, 10 (2), pp. 28-33

80. Urde, M. (2003) Core value-based corporate brand building. European Journal of Marketing, 37 (7/8), pp. 1017-1040

81. Veljković, S. (2009) Marketing usluga. Beograd: Univerzitet Singidunum

82. Vranešević, T. (2007) Upravljanje markama. Zagreb: Accent

83. Walker, S. (2002) Jung and the Jungians on Myth. London: Routledge

84. Willig, C. (2013) Introducing qualitative research in psychology. Maidenhead: Open University Press 


\title{
SERVICE BRAND IDENTITY ANALYSIS
}

\author{
Dinko Jukić \& Božica Dunković
}

\begin{abstract}
Summary
The paper analyses the characteristics of brand identity. The notion of brand identity is first defined, and then the notion of brand image is redefined, analysed and synthesized. The identity and image of the brand is presented from a communicative and semiotic aspect and compared with the role of myth and consumer self-image. The aim is to research, present and analyse the identity and image of the service brand in accordance with the consumer paradigm. The paper consists of three parts. The first part analyses the brand identity from a semiotic and psychological aspect, and the second part discusses and analyses the content of the brand image. Finally, the perceived quality of service is discussed. The brand is first of all a consumer impression and only then a cognitive value. Brand building involves making a difference, and creation takes place using the mental structures of consumers. We view the image as a result of the communication process, but also as a consumer image and experience. The image of the service is created equally by the employees, but also by the immediate experience of the consumers. It is concluded that the role of perceived service quality arises from consumer satisfaction and corporate image.
\end{abstract}

Keywords: brand; identity; image; customer; service. 